\section{A Filipino Evangelical Christian's (Re)valuation of the Hebrew or Jewish Shabbat as an indigenous teaching-learning model}

Grande, Eric Joyce DC. $\triangle$

University of the Philippines Los Baños, Philippines (edgrande@up.edu.ph)

Received: 9 September 2020

Available Online: 4 December 2020
Revised: 16 October 2020 DOI: $10.5861 /$ ijrse. 2020.5728

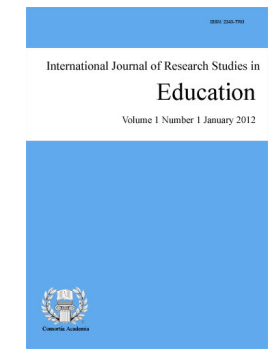

ISSN: $2243-7703$ Online ISSN: 2243-7711

Accepted: 10 November 2020

OPEN ACCESS

\title{
Abstract
}

The last 20 years or so can be characterized by Filipinos' growing awareness and deepening (re)connection to the Hebrew or Jewish roots of the Christian faith. This is evident, at least, among Evangelicals. Some reconfigured into Messianic churches or congregations. One of their distinctives is the teaching and observance of the Feasts of the Lord or moedim, more commonly known as Jewish Feasts, and these include Shabbat (Sabbath in English). More recently, with the education reform or Kto12 that started in 2016, Judaism is now taught through the subject World Religions and Belief Systems in Senior High School (SHS). Filipino youths are now more exposed not only to Jewish culture but also discourse without necessarily visiting a synagogue. More specifically, (1) I present five versions of the Shabbat seder/siddur or liturgy/prayer book, which were obtained in the Philippines within the last five years. These serve as qualitative data. Further, (2) I explain Shabbat in its Hebrew context through the Modern Hebrew language, hence, visual analysis. Lastly, (3) I elaborate Shabbat as an indigenous pedagogical or teaching-learning model for which textual analysis was done. With a global pandemic due to COVID-19, education has transitioned into modular or online mode at home just like in the Philippines. Shabbat may offer fresh ideas and insights on how "forced" homeschooling can be undertaken or what topics must be emphasized or integrated.

Keywords: Evangelical Christian; Messianic; Shabbat; seder; teaching-learning model 


\section{A Filipino Evangelical Christian's (Re)valuation of the Hebrew or Jewish Shabbat as an indigenous teaching-learning model}

\section{Introduction}

Mainline Christian denominations in the Philippines, such as Evangelicals and Roman Catholics alike, officially declared 2020-2021 as the Jubilee or $500^{\text {th }}$ anniversary of Christianity or Christianization of the nation. That said, it must be reckoned that 500 years ago or around that time, the Jews in Spain were persecuted and expelled. This is why many speculate that some of those who reached the archipelago in 1521 were Jews who had converted to Christianity. Even after conversion, they were not spared from such hostility. Many of the, especially the affluent, left Spain in the name of explorations and voyages in search of, for instance, Spice or Indian Islands. Benigno (2008) historicizes that Don Pacheco Maldonado reported to the King of Spain in 1570 that Luzon was already inhabited by Jews.

Jewish presence in the Philippines became more apparent at the onset of World War II (WWII). The Embassy of Israel Manila (2015) chronologizes that, at the peak of the persecution of the Jews in Europe in 1938, former President Manuel Quezon launched the Open Door policy. He initially "issued 10,000 visas for them and considered expanding this to 100,000, but only 1,300 reached the Philippines [from 1937 to 1942]". In fact, he dedicated the Marikina Hall for the Jewish refugees in 1940. However, the Japanese invasion in 1941 got in the way of this humanitarian project. Nevertheless, their presence explains why there were synagogues in Manila before the WWII. Besides, the Jewish section of the Manila North cemetery has been maintained since then. In 1947, the Philippines was the only Asian nation in the United Nations (UN) that voted "yes" or in favor of the creation of the Modern State of Israel. This also makes the Judeo-Christian tradition not only a matter of religion or theology but culture in general involving economy, education, politics, disaster and risk management, among others. By implication, the same presence is responsible for not only the observance but also artifacts of Shabbat. For instance, I found a Jewish hymnal that contains Shabbat seder or liturgy at a trading house in Manila. It was published in 1957, the third edition of what was originally compiled and printed in 1932 by The Central Conference of American Rabbis. The said material predates the treaty in 1958 that guarantees the "perpetual peace/lasting friendship between the Republic of the Philippines and the State of Israel” (Balais, 2018, p. 9).

Within the last 20 years or so, there is a growing awareness on the significance of the Hebrew roots of the Christian faith, at least, among Evangelicals. For instance, a network of Evangelical and/or Born-Again churches realized the centrality of the Feasts of the Lord, which has been dubbed as Feasts of the Jews. Passover was observed at a national gathering in 2012. Shabbat, being a weekly celebration, has also been encouraged. Even before this, some autonomous groups had fully embraced Hebrew roots, hence, Messianic churches or congregations. The diversity or range of Messianic groups in the Philippines merits another study.

More recently and due to the ongoing education reform, Judaism is now taught as one of the topics in the subject World Religions and Belief Systems in Senior High School (SHS). The curriculum presents that each major religion has the following components: (1) elevation of the self to a higher dimension of existence, (b) framework of transcendent beliefs, (c) texts, or scriptures, (d) rituals, and (e) sacred spaces (Department of Education/DepEd, 2014). Shabbat can demonstrate the connection of these components. Since 2016, younger Filipinos are now more exposed to Jewish discourse. This opens up Judaism and Hebrew culture in general not only as an academic topic but also as a research interest. It also situates Jewish Shabbat into the Filipino discursive space.

\subsection{Objectives of the study}

With Shabbat, being a feast or a ritual that commonly requires reading certain portions of the seder or 
A Filipino Evangelical Christian's (Re)valuation of the Hebrew as an indigenous teaching-learning model

liturgy as sacred text, I collected or compiled copies distributed in various Shabbat celebrations or gatherings where I was invited. In this paper, (1) I present these versions as (re)constructions of the Evangelical or Born-Again, and Messianic believers. Moreover, (2) I explain Shabbat in its Hebrew or Jewish context, that is, decoding or making sense of it using the Modern Hebrew language, which is more accessible and available than Aramaic. In Modern Hebrew, it is spelled or written as (shin-beth-tav). Lastly, using the seder published online by Hebrew for Christians, I (3) elaborate Shabbat as a heuristic, holistic, and indigenous pedagogical or teaching-learning model.

\subsection{Significance of the study}

Considering observant Evangelical and Messianic congregations and Basic Education (BE) teaching Judaism in SHS, Shabbat is a fresh church and classroom discourse. It is instructive to explore how it is being adapted/adopted into Filipino ethnicities and spiritualities. Just like Christianity, Judaism is also observed diversely by various denominations or congregations, such as Ultra, Modern, or Non-Orthodox, secular, humanist, among others. My paper attempts to situate a Filipino Evangelical Christian's account or voice within such range of diversity. To add, there are very few researches on this yet, at least, in the Philippines. Out of 765 abstracts from eight research conferences on culture, education, history, indigenous studies, religion, among others, within May 2018 until October 2020, there are only 11 that point to Judaism or Hebrew tradition. One looks into a dialogue of the Judeo and Christian traditions, while five others are preliminary versions of this paper (Grande, 2018; 2019a \&2019b; 2020a and 2020b). The other five are relevant topics to the Hebrew or Jewish tradition. Besides, Judaism emerged ahead of Islam and Christianity. This kind of inquiry may lead to a deeper understanding and better appreciation of the convergence and divergence of these traditions of faith.

\subsection{Limitations of the study}

Meanwhile, I acknowledge the limitations of this research. One is access to materials that are written by Jews themselves or by other nationalities. While the Torah, the first five books of the Bible, is accessible, the Talmud is not. Comprehensibility of the Hebrew texts was compensated for by attending a basic conversational Hebrew class in 2017. Because I do not have someone to speak Hebrew with, I shifted to basic reading and writing. I also do not have access to any Jew in the country. A member check or a feedback could have enhanced this research text. Because of the current restraints due to the global pandemic, I also have not explored available literature at seminaries and schools of theology of several denominations.

\section{Literature review}

\subsection{Feasts of the Lord}

Jill Shannon (2012), an American Jewess who already came to the Philippines a few times to teach about Hebrew roots of the Christian faith, lists the Feasts of the Lord: Passover (Pesach), Unleavened Bread (Hag HaMatzah), First Fruits (Bikurim), Pentecost (Shavuot), Trumpets (Yom Teruah), Day of Atonement (Yom Kippur), and Tabernacles (Sukkot) (pp. 133-134). Each of these happens once a year. She explains that "these seven feasts can be divided into (1) four spring feasts and (2) three fall feasts" (p. 133). However, this paper focuses on Shabbat, which is observed every week from sundown of Friday until sundown of Saturday. She asserts that although these are commonly known as Jewish holidays, these are referred to in Scriptures as Feasts of the Lord (Leviticus 23;1-2). While these were originally mandated to the Jews, these can also be celebrated by other peoples and followers of the Lord in all nations. Besides being a mitzvot or commandment, there are two other Hebrew notions that define and describe these feasts. One is moed or an "appointed time or season," hence, divine appointment. She elucidates that as the "sun, moon, and stars were made for times and seasons" (Genesis 1:14), these feasts specify certain dates in the calendar that "must be set apart for God and away from the normal business of life" (Shannon, 2012, p. 132). The other is mikrah or a holy convocation, a sacred assembly or a 
rehearsal of God's past, present, and future acts... [because each feast] is "remembering or foreshadowing an aspect of Messiah's ministry" and an "everlasting ordinance to all generations" (p. 132).

Related to these feasts, including Shabbat, is the notion of foreshadow. Perry Stone (2013) quotes Colossians 2:16-17 that says "so let no one judge you in food or in drink, or regarding a festival or a new moon Sabbaths, which are a shadow of things to come, but the substance is of Christ" (p. 11). He clarifies that "a shadow is not an actual image of something, but it reveals its form" (p. 11). With light, this is the actual image is revealed. In its Greek context, shadow, he continues, is "an imperfect image or copy that is a reflection of the true substance" (p. 12). Meanwhile, the shadow is the reflection of light that is cast upon the actual object. He elucidates that a "shadow implies that the reality is yet to come, but a reflection of what is to come is found in the past, or in the shadow" (p. 12). Further, he revisits Shabbat. It "was established by God at early creation, when after six days of creative work, God rested on the seventh day" (Genesis 2;2). Every seventh day is set aside as a Sabbath or rest for the people of Israel and is perpetual from generation to generation (Exodus 20:10-11). Ultimately, this practice initiated "a pattern for all mankind to set aside a day of rest during the week" (p. 21).

\subsection{Model of liberation}

Lenn Goodman (2017) conceptualizes Shabbat as a model of liberation because it is a sanctified day of rest. The seder, in fact, recounts the deliverance of the Israelites from Egypt. Meanwhile, the term "multitudes" in the Biblical account refers to other nations who were also liberated from slavery in Egypt, hence, it is not only celebrated by the Jews. Moreover, in this framework, individuals cease from their labor and relish their identity, that is, they are created after God's own image. Slaves are not also required to work. "Animals are also rested" (p. 11). He adds that Shabbat is "an emblem and an opening of human dignity" including the dignity of labor (p. 47). Shabbat, being the first day of the week, marks that the next six days are opportunities to "contribute to the general wellbeing and build up or improve the world" (p. 47). "The goal is not only leisure but a certain frame of mind... and refinement character refinement." (p. 61).

\subsection{Indigenous Knowledge Intelligence (IKI)}

Alexander Maune (2017) introduces indigenous knowledge intelligence (IKI), which is "a competitive strategy and imperative for developmental policies especially in developing nations or an alternative way that can promote development in poor rural communities in many parts of the world" (p. 173-174). He summarizes IKI as "intelligence in action" (p. 179). He explains that the Torah (Written Law) and the Talmud (Oral Torah) of the Jewish people are an example. These have been the "cornerstone of the Jewish culture, the creative strength of the Jewish people, and the backbone of Jewish history and economic development" (p. 176). He laments that colonialism and cultural imperialism have neglected these; hence, these be taught by "parents to their children" (p. 177). In a way, IKI is a reaction to the failure of Western models or scientific/academic knowledge that are applied in indigenous contexts. This Jewish IKI is accessible through the Bible, which showcases knowledge or intellectual traditions. For instance, Genesis presents they have a notion of "a tree of knowledge of good and evil in a garden" or paradise on in other translations (p. 175). Even after eviction from the garden, Exodus records that they have written and spoken traditions. They also have an account about the origin of different languages. Throughout history, political powers that conquered them attempted to eliminate these traditions, but these have been preserved at a cost. From its Paleo or Phoenician and Aramaic origins, these are still comprehensible through the Modern Hebrew language. An integral component of the said IKI is Shabbat. Between Friday sundown until Saturday sundown of each week, families make time to gather at home or as a community at a nearby synagogue to study the Torah and Talmud. They do so "either by themselves or with a rabbi and with all the commentaries and interpretations" (p. 187). 


\subsection{Interpretive tradition}

That said, Shabbat is largely interpretive. Theorizing it as an indigenous teaching-learning model takes off from the constructivist or interpretivist research tradition. In particular, it revisits symbolic interactionism as a conceptual resource. It has three assumptions: “(1) people act toward things based on the meanings of those things to them, (2) meaning is derived from social interaction, and (3) meaning is the result of an interpretive process used by people to deal with [something] that they encounter. [Moreover], the interpretation of the stimuli has two phases: (1) the actor indicates to himself or herself the things toward which he or she is acting and (2) the actor selects, checks, suspends, regroups, or transforms the meanings in light of the situation" (Jaccard \& Jacoby, 2010, p. 301). As regards meaning, Stone (2013) enumerates three layers: (1) plain or simple meaning of a narrative, (2) practical application or how can it be applied for our present lives, and (3) prophetic layer, which is "uncovered when we see people, events, or holy days have within them the imagery of prophetic events that are to occur in the future." (p. 15). Further, Jewish sages mention seven layers of meaning; however, I propose a pedagogical conceptualization of Shabbat.

\section{Methodology}

As stated earlier, this study was developed through the constructivist-interpretivist research paradigm, hence qualitative research or tradition. More specifically, I collected qualitative data through ethnography, which is popularly used in social science and humanities research projects. It presents a research method or, "more accurately, a set of methods for understanding and making sense of cultural and social worlds" (Coffey, 2018, pp. 2-3). Ethnography being chronicles of complexity involves “(1) experiencing through participant and non-participant observation, (2) enquiring through formal and informal interview, and (3) examining through the analysis of documents and cultural artifact” (McCarty, 2015, p. 84).

In 2017-2018, there were many events in the Philippines in line with the $70^{\text {th }}$ founding anniversary of the Modern State of Israel. There were big (national and regional) or small gatherings like the weekly Shabbat in the Philippines. In a small group context, I did not only participate and observe but was also taught how to facilitate or lead through direct instruction and demonstration. Such gatherings had leaders of Evangelical and Messianic groups alike and also rabbis of different nationalities but are Jews in a way or another and with whom I had limited conversations. I extended my search for additional information and ideas by studying online sources. True enough, diversity in Judaism is apparent. In the said celebrations, seder was distributed, hence, my collection of documents or artifacts, which were analyzed as visual and texts.

\section{Results and discussion}

\subsection{Versions of the Shabbat Seder}

Years 2016-2018, at least, among Evangelical and Messianic believers, featured many extravagant gatherings in line with the celebration of the $70^{\text {th }}$ founding anniversary of the Modern State of Israel. It is within this context that I obtained five versions of the Shabbat seder. I present these based on the year of acquisition.

In 2016, the Intercessors for/ the Philippines (IFP) (n. d.), realizing not only the theological but prophetic value of the Feasts of the Lord, held The Feast of Passover: A Worship Symposium with Jill Shannon as speaker. In that same event, the weekly Shabbat was also encouraged or promoted; hence, copies of the Simplified Shabbat Dinner Guide were disseminated. It actually got translated into Filipino. The material indicates that it is mainly derived from an online material. Thus, I accessed A Shabbat Seder: A Simplified Guide for Christians by John Parsons of the Hebrew for Christians website. The following year, 2017, I was given a copy of Shabbat Siddur from Ysraphil Network Development Organization (YNDO). The said group was pioneered by an American Messianic Jew but had already gone back to United States. Interestingly, that same year, I surprisingly came across and so purchased from a trading house Union Hymnal Songs and Prayers for Jewish Worship, 
which includes Sabbath (pp. 461-474). Hannukiah or the Hannukah lampstand, candle holders, seder plate, among others, were on sale. At the Shalom Symposium in 2019, I also obtained Erev Shabbat from Grain New Wine and Oil Ministries (GNWOM) (n. d.), a renowned Messianic church with congregations in different parts of the country.

The trend or pattern that these versions elicit is that the seder originated among American Jews, who shared or imparted it with Filipino Messianic and some Evangelical believers alike, who, in a way or another, contextualized, indigenized, or localized it, hence, reconstructions. The seder varies in structure and substance depending on the ethnicity or nationality (Israeli or American Jew) and spirituality or theology (Christianity or Judaism) of the congregation. It must be noted that the said Filipino Evangelical and Messianic believers alike do not need to convert to Judaism. Theirs is fundamentally (re)connecting to and (re)living the Hebrew roots of Christianity.

\subsection{Jewish or Biblical metaphors}

In childhood, I learned Shabbat being the equivalent of Sunday worship. Seventh Day Adventists (SDA) interpret and observe it differently. Theirs is practically on a Saturday. Meanwhile, Jehovah's Witness (JW) meet on Fridays. In this section, I will discuss a few metaphors that have been used to illustrate Shabbat, and I will not differentiate the interpretations and observances of several Christian denominations. It is instructive to revisit the nuances of the Hebrew letters that constitute the word. It is spelled or written in Hebrew as שבת. Unlike the Roman script that is phonetic or sound symbols, the Hebrew characters are ideographic, which suggests that each character has its own meaning. Basically, it represents a literal object. Hence, a word can be a narration, interpretation, among others. The first letter is shin, which literally points to a tooth or flame of fire. Beth or bayit is a representation of a house or a dwelling, while tav is a sign that appears in the form of a cross, which suggests an intersection, hence, a covenant.

Rabbi Munk (1983) confirms that each letter of the Hebrew alephbet connotes special meanings. As stated earlier, it can elicit plain, practical, and prophetic meanings besides what sages call seven layers of meaning. For instance, shin also suggests Holy Spirit being the Comforter, hence, peace. Beth signifies creation and preparation for the world to come. The former refers to creation as our present dwelling place, and the latter an eternal home. Lastly, tav signifies perfection of a cycle pointing to the future destiny of humankind. Hence, Shabbat is being at home in God's company or peace, creation, and coming eternal kingdom. It is indeed a rehearsal or reenactment of God's past, present, and future affairs.

One classic example is when Adonai or God Himself made a covenant with Abraham as regards the birth of the nation of Israel (Genesis 15:12-21). An ancient Eastern way of ratifying a treaty involves animal sacrifice "cut in half lengthwise, and each piece on either side of a shallow gully. The blood of the animal runs down the gully to form a pool. The two parties who were entering into covenant would both walk past each other through the blood and take an oath" (Shannon, 2012, p. 20). However, in this case, both parties did not walk through the blood. Abraham was in a deep sleep at the setting of the sun, so it was God, in the form of a blazing torch, who walked through the sacrifice. With a setting sun and resting Abraham, it can be speculated that this must have taken place on a Shabbat.

Another instance or metaphor is the entry of the High Priest into the Tabernacle only once a year or on the Day of Atonement, the holiest day among the Jews (Leviticus 23: 16-32). He enters the Temple Court past the brazen altar where animal sacrifice is done. Eventually, he goes into the Holy Place, which hosts the menorah or lampstand, and finally approaches the altar of incense, behind it is the Most Holy Place, where the Ark of the Covenant is kept. He presents to the Lord an offering to atone for the entire nation. That day, the Jewish people observe a 24-hour fast instead of a feast.

I also include as an example or a metaphor the preparation and consequent selection of Esther as queen to King Ahasuerus (Esther 2:8-18). The young lady went through a process of beautification and purification with 
A Filipino Evangelical Christian's (Re)valuation of the Hebrew as an indigenous teaching-learning model

oil of myrrh for six months and spices and cosmetics for another six months. Each potential queen was called into the King's chamber, and anything she desires is granted. Eventually, Esther was not only chosen and crowned queen but also loved by the King. Up to this day, her tomb is a tourist destination in Iran. This suggests a very intimate meaning of Shabbat (Selvaraj, 2012). By implication, Shabbat is a reenactment or a rehearsal of a wedding feast. This practice is evident in either a Christian or a Jewish wedding. Candles are lit, the couple either meets or marches together towards a decorative canopy called chupah, under which they publicly declare their vows, hence a covenant, and relish a symbolic meal as a husband and a wife.

This tradition clearly contextualizes the need of having more than enough oil to keep the lamps burning while waiting for the bridegroom (Matthew 25:1-13). Five virgins took more than enough, while the other five ran out of oil. The former, who had their lamps burning were allowed entry to the wedding feast. The latter were denied. Remarkably, the church is referred to as the bride or wife of Christ (Ephesians 5:22-33). In a typical synagogue or Kabbalat Shabbat and towards the end of the song Lecha dodi, they turn about face and look toward the door as if acknowledging the entrance of a bride. They eventually face the bema or right where the rabbi speaks or leads.

\subsection{Shabbat as a teaching-learning model}

Jaccard and Jacoby (2010) define model as concrete expression of a conceptualization. In my paper, Shabbat is the expression or external symbol system used to conceptualize indigenous education. Further this conceptualization has 10 components or premises presented as 10Ms (Grande, 2010 unpublished): management, mentoring, monitoring, mentees, mark, motivation, material, medium/media of instruction, money, and method. I initially used this in helping the management team of a district hospital develop their adult education program for employees and information campaign for patients and watchers in line with quality assurance (QA) in 2010 and 2011. I now use the same lens in making sense of Shabbat.

In the context of Shabbat observed by a nuclear family, (1) management or who plans and oversees, (2) mentoring or who facilitates/teaches, and (3) monitoring or who regulates are all under the care of the parents or both the father and the mother. The (4) mentees or who are taught are no other than the children. The (5) mark or how is assessment or evaluation done takes on another meaning or context of learning. It is not directed towards a numerical grade or equivalent of an outcome or something done but of what one should become. A prayer recited by parents for children is that sons be like Ephraim and Manasseh, the son of Joseph, who became a Prime Minister of Egypt, and daughters be like the Sarah, Rebecca, Rachel, and Leah, the mothers of the 12 tribes of Israel. By tradition, (5) the motivation or why households observe is because it is a mitzvah or a commandment. For sure, different observant Jewish, Evangelical, and Messianic households will cite other reasons. The (7) material or what is taught varies, but a Shabbat usually has a seder or liturgy. Besides the seder, there are readings or materials for study: Parashat, Torah, and Haftarah among Orthodox Jews. Among Evangelical and Messianic groups, there is an additional reading, the Brit Cadashah. Early on, these promote a reading culture in Hebrew among both children and adults. In terms of (8) medium/media of instruction or what languages are used, it involves English and Hebrew, at least, among observant American Jews, hence bilingual. It is multilingual in the case of observant Filipino believers. While the seder is in English and Hebrew, spontaneous prayers and conversations can be in their respective first languages or mother tongue besides the national language. Another premise is (9) money or how much does is cost. In this context, cost does not refer to the tuition fee or maintenance and other operating expenses, but basically for the food and the photocopy of materials. In terms of food, the family must live within their means, and copies of the seder must be properly kept as these are used weekly. Conceptualized as a teaching-learning model, Shabbat also has a (10) method or how teaching and learning are done.

Hebrew for Christians explains its threefold essence: (1) rest or menuchah, (2) holiness or kedushah, and joy or (3) oneg (p. 3). If observed after sundown of Friday, it is called Erev Shabbat. If it is at sundown of Saturday, it is called Havdalah. Using the Hebrew for Christians version of the seder, I discuss how it is done, hence, 
method. The significance of each part is also presented and linked to a contemporary education parlance:

Preparation - While Shabbat is typically a household affair, a family may intently consider whom to invite. They can be friends, but those in need and are most likely alone during this time are preferred. In today's education parlance, this is inclusion or sincere regard for the marginalized. Besides, the family must be keen about what food to prepare for the celebration. Parsons (n. d.) opine that while Christians are not legally required to follow all of the details, pork-based food should be avoided, and this has to do with healthy food or healthy living in general. Prior to Shabbat, each family member must have read the reading portions before Friday sundown. Shopping, cooking the food, setting the dining table, and washing kitchen utensils are the domestic aspect. These practically shows how special each Shabbat is.

Giving of tzedakah (charity) - This involves putting a few coins in a box. By tradition, the monetary collection is meant for "repairing" the world. Each one, including young children, is encouraged to give even the least or smallest coin. This teaches social responsibility. Even before approaching God at his table, we are expected to think of or fend for our fellow. At a time of a global pandemic and natural disasters just like what recently happened in the Philippines, the weekly collection can be appropriated for relief operations.

Lighting of the Shabbat candles - Jewish tradition requires "the eldest woman in the household to light the candles 18 minutes before sundown of Friday evening and then waves her hands over the flames and covers her eyes with her hands" so that she will not see the flames. A prayer is recited. It acknowledges God as the light to the nations, not just of the home. Head on, Shabbat meals relish global citizenship and not only international mobility.

Berakah Kohenim (Priestly Blessing) - A prayer is invoked for the protection of the children. Besides, that the face of God be upon the children suggests that they be reminded that they were created after God's own image, hence, an ancient manner that acknowledges the sanctity of human life, and that each child is also a heritage from God. Shalom or peace or wholeness is also pronounced. Parents are also encouraged to more intimately and spontaneously express their love and appreciation to their children. More than an expression of parental responsibility, it is, in fact, an exercise of priestly authority of parents over their children. Non-Jews may also practice their own expressions of respect and endearment such as kissing of hands or kneeling before the parents.

Kiddush (Sanctification of the Wine) - A prayer is recited to bless the wine or fruit of the vine. This is led by the father while holding a cup of wine. The prayer reckons the first Shabbat, which commenced after the sixth day of creation (Genesis 1:31;2-3) and the liberation of the Israelites from Egypt, hence, a heritage and a memorial. A sense of history or reconnecting to the past is explicitly taught or transmitted. Everyone partakes of the wine after reciting the prayer.

Netilat Yadayim (Washing of the Hands) - This is only ceremonial and undertaken right before blessing and eventually partaking of the bread or challah. Everyone is encouraged to have washed his or her hands before seating at the table. This is connected to hygiene and sanitation as everybody is also discouraged from speaking after the blessing or prayer is recited. Hence, sanctification takes place not only in the spiritual but also the natural realm.

Challah (Sanctification of the Bread) - Parsons (n. d.) details that "after washing, the father draws the knife across the bread making a slight indentation to indicate the place for cutting, raises the loaves, and recites a blessing" (p. 12). The blessing acknowledges that bread was brought forth from the earth. Together with the fruit of the vine, the bread from the earth points to the central role of agriculture, particularly, food production and processing. In particular, the former is beverage, and the latter pastry. Stewardship takes off from the awareness of its source. This is relevant because of global food security issues. Eventually, the father "cuts a piece of the bread for himself, dips it in salt or sprinkles salt over the slice, or he cuts other pieces and distributes these to those seated around the table" (p. 12.). 
A Filipino Evangelical Christian's (Re)valuation of the Hebrew as an indigenous teaching-learning model

Shabbat Meal - Amid or after the meal, someone, usually the father, being the head of the home, delivers a commentary, explanation, reflection, or reaction to the weekly Torah reading portion. Songbooks or hymnals, such as the one I bought from a trading house, may be necessary for the singing. Observant Jews usually sing songs in Hebrew, while Filipino Evangelicals and Messianic groups in the Philippines, due to language limitations, render choruses about the death and resurrection of the Lord Yeshua (Jesus in Hebrew). A renowned Jewish congregation in America is fond of reconfiguring classic songs into contemporary and customized or totally contemporary tunes. As explained earlier, Shabbat is not a luxury but a refinement of character, which is close to personal development. While the food nourishes the body, the Word or Torah study nurtures the soul and spirit. After the meal, one can simply enjoy the company of family, friends, and invited guests or take a nap or visit friends, but Torah study is a core feature.

Birkat Hamazon (Grace after the Meal) - Parsons (n. d.) emphasizes that it is not customary for the Jews to "say grace" before meals. Instead, it is done after the meal. Further, this is also a literal observance of "tasting and seeing that the Lord is good" (Psalm 34:8) before thanking Him. This teaches gratitude in its highest form. Such sense of gratitude does not only cover the provisions within the past week but also decree that, in God's goodness, the needs for the coming week will be provided for. This is the hope and assurance that the blessing or prayer invokes.

Thanking God for Salvation - This seems to be a distinguishing feature of the seder used by Christians whether Evangelical or Messianic. This is essentially a blessing or a prayer that looks up to YHVH, the Father of Glory, who sent His Son Yeshua HaMashiach or Jesus Christ, the only way to salvation.

With Shabbat as an indigenous teaching-learning model, I also highlight three points that Christian education, which is the learning taking place among various ages in the usual context of Evangelical Christians in the Philippines, may (re)consider. First is intentional reading and reciting. I believe Christian education being deliberate on this can necessitate the academic/technical/professional reading proficiency of its members, particularly the youth. Another is the emphasis on remembering and reflecting. This promotes not only critical thinking and a sense of heritage but active participation in the (re)construction of history. Shabbat underscores identity and destiny. Lastly, reconnecting and recommitting is another salient feature. The seder is explicit about affirming connection with tradition, people or nation, and God.

\section{Conclusion}

Jewish presence in the Philippines has a long history. More recently, there is growing awareness and deepening (re)connection of Filipino Evangelical and Messianic believers to the Hebrew roots of Christianity. Judaism is also taught as a topic in one SHS subject. My paper reviewed five versions of the Shabbat seder as social (re)constructions that are largely influenced by the ethnicity or nationality and spirituality or theological leaning of a congregation or group uses it. Further, I elaborated the meaning of Shabbat in Modern Hebrew and cited a few metaphors used to illustrate its essence. Lastly, through symbolic interactionism as a conceptual resource, Shabbat is theorized as an indigenous teaching-learning model using the premises of 10Ms: management, mentoring, monitoring, mentee, mark, motivation, material, medium of instruction, money and method. I amplified method by discussing the typical parts of the Hebrew for Christians version of the seder. Interestingly, Shabbat had been instituted shortly after creation, but it has not failed to be relevant as it has not yet ceased from being practiced by different Jewish and Christian congregations. It may offer ideas or insights on how "forced" homeschooling or Christian education may be sustained or enriched at this time of global pandemic due to COVID-19.

\section{References}

Balais, D. A. (2018). Message. $70^{\text {th }}$ Israel Independence Day and $60^{\text {th }}$ Year of Israel-Philippines Bilateral Relations. Souvenir Program. Manila, Philippines. 
Grande, E. J. D.

Benigno, N. C. (2008). Israel and the Philippines. Centuries-old ties that bind. God bless Israel today and beyond. A joint celebration of thanksgiving with rejoicing. Souvenir program. Quezon City.

Coffey, A. (2018). Doing ethnography. In U. Flick (Ed.). Doing ethnography: The Sage qualitative research kit (2nd ed.). Thousand Oaks, CA: Sage Publications.

Department of Education. (2014). Senior High School Course Guides. Retrieved on August 22, 2019 from http://www.edu.gov.ph

Embassy of Israel Manila. (2016, June). Thank you Philippines. Poster Exhibit. University of the Philippines, Los Baños, Laguna, Philippines.

Goodman, L. E. (2017). Judaism: A contemporary philosophical investigation. New York and London: Routledge Taylor and Francis Group. https://doi.org/10.4324/9781315639413

Grain, New Wine, and Oil Ministries. (n. d.). Erev Shabbat. Photocopy.

Grande, E. D. (2010, November 2-3). Workshop on continuing adult education in line with PHI accreditation. Lecture and workshop. Cabarroguis, Quirino, Philippines.

Grande, E. D. (2018, November). Emerging and expanding sites of holocaust education in the Philippines. Paper presented at the $2^{\text {nd }}$ International Conference on Multidisciplinary Filipino Studies, De La Salle University Dasmariñas City, Cavite, Philippines.

Grande, E. D. (2019a, July 4-6). A growing understanding of the Hebraic roots of the Christian faith in the Philippines. Paper presented at the $5^{\text {th }}$ Philippine Association for the Study of Culture, History, and Religion, Divine Word College, San Jose, Occidental Mindoro.

Grande, E. D. (2019b, December 11-2). Shabbat celebrations in the Philippines: Reconnecting with the Hebrew roots of the Christian faith. Paper presented at the Pagdiriwang: Festivals as Heritage International Conference on Folklore, University of the Philippines Diliman, Quezon City, Philippines.

Grande, E. D. (2020a, January 29-31). Rediscovering and recovering indigenous knowledge and restoring identities through Shabbat. Paper presented at the $2^{\text {nd }}$ International Research Conference on Local Knowledge and Indigenous Studies, University of Saint Louis, Tuguegarao City, Philippines.

Grande, E. D. (2020b, October 17). An Evangelical Christian's exploration on the Hebrew notion of education as dialogue: The Hebrew or Jewish Torah and Talmud as Indigenous Knowledge Intelligence (IKI). Paper presented at the $9^{\text {th }}$ National Conference on Catechesis and Religious Education via Zoom, De La Salle University Manila, Philippines.

Intercessors for the Philippines. (n. d.). Simplified Shabbat dinner guide. Photocopy.

Jaccard, J., \& Jacoby, J. (2010). Theory construction and model-building skills: A practical guide for social scientists. New York and London: The Guilford Press.

Maune, A. (2017). Indigenous Knowledge Intelligence and African development. In P. Ngulube (Ed.), IGI handbook on research on theoretical perspectives on indigenous knowledge systems in developing countries (pp. 173-125). PA, USA: IGI Global. https://doi.org/10.4018/978-1-5225-0833-5.ch008

McCarty, T. L. (2015). Ethnography in language planning and policy research. In F. M. Hult \& D. Cassels Johnson (Eds.), Research methods in language policy and planning (pp. 81-93). West Sussex, UK: John Wiley and Sons, Inc. https://doi.org/10.1002/9781118340349.ch8

Munk, M. L. (1983). The wisdom in the Hebrew Alphabet. Brooklyn, NY: Mesorah Publications Ltd.

Parsons, J. J. (n. d.). A Shabbat seder: A simplified guide for Christians. Retrieved on November 19, 2016 from http://www.hebrew4christians.com

Selvaraj, S. S. (2012). A rose for Jesus. Mandaluyong City, Philippines: Intercessors for the Philippines.

Shannon, J. (2012). Israel's prophetic destiny: If I forget Jerusalem. PA, USA: Destiny Image Publishers.

Stone, P. (2013). The prophetic future concealed in Israel's festivals. TN, USA: The International Office of Voice of Evangelism Ministries.

The Central Conference of American Rabbis. (1957). Union hymnal: Songs and prayers for Jewish worship $\left(3^{\mathrm{rd}}\right.$ ed.). USA: Author. 